\title{
Chapter 18 \\ Potential Impacts of Climate Change on Habitats and Their Effects on Invasive Plant Species in Danube Delta Biosphere Reserve, Romania
}

\author{
Mihai Doroftei and Paulina Anastasiu
}

\subsection{Introduction}

It is widely accepted that climate change effects have repercussions everywhere around us; the Danube Delta Biosphere Reserve (DDBR) is no exception. The spreading of invasive plant species is mainly influenced by climatic factors. Most invasive species, regardless the place of occurrence, follow the same climatic pattern as in their place of origin (Richardson and Pysěk 2006). Changes of climatic features showed habitat alteration by decreasing, increasing or shifting of species' range in size and abundance (Leech et al. 2011). In climate change context, one of the effects is the spread and persistence of invasive plant species in natural habitats and the interference on plant community's structure. These opportunist species take advantage of every climatic change in order to expand their survival rate leading to the loss of the native species (Hellmann et al. 2008). The aim of the study was to identify the spreading potential of invasive species within DDBR habitats by their present features of adaptation and their occurrence in plant communities considering climate change impacts. Annual climatic values (temperature, precipitation) collected between 1961 and 2007 from the eastern (Sf. Gheorghe - Black Sea shore) and western (Tulcea) meteorological stations located in DDBR were used and processed. DDBR is situated in South-East Europe, respectively in SouthEastern Romania. As a biosphere reserve, this wetland is also the largest $\left(5,800 \mathrm{~km}^{2}\right)$ Romanian Natura 2000 site (ROSCI 0065 and ROSPA 0031). It is a fluvial-maritime floodplain on two bioregions, a steppic and a pontic one

\footnotetext{
M. Doroftei $(\bowtie)$

Department of Biodiversity Conservation, Danube Delta National Institute for Research and Development, Babadag Street, No. 165,820112 Tulcea, Romania

e-mail: doroftei@indd.tim.ro

P. Anastasiu

Department of Botany and Microbiology, University of Bucharest, Aleea Portocalelor 1-3, Sector 5, 060101 Bucureşti, Romania

e-mail: anastasiup@yahoo.com
} 
(Ciocârlan 2011). By means of management measures, adaptation is undertaken in order to reduce potential impacts of climate change on DDBR habitats.

\subsection{Methods}

The spreading potential of invasive species was analysed by their present features of adaptation, plant community qualitative indices (Braun-Blanquet scale) and annual climatic values (temperature, precipitations). The time-frame 1961-2007 data was used from the eastern (Sf. Gheorghe - Black Sea shore) and western (Tulcea) meteorological stations located in DDBR. The obtained data was compared to the reference (Sanda and Arcuş 1999; Hanganu et al. 2002; Ciocârlan 2011). Subsequently, the data was interpreted by means of mapping software ArcMap 9.1 and presented on a digital map.

\subsection{Results: DDBR Habitats and Invasive Plant Species}

Presently, 180 plant communities have been reported within DDBR (Sanda and Arcuş 1999; Hanganu et al. 2002), integrated within 29 habitats according to the European Habitats Directive (92/43/EEC). A list of 168 alien plant species, based on references and field research done during 2009-2011, has recently been compiled (Anastasiu 2011). Twenty-one plant communities mainly consisting of alien plants identified in the field are listed in Table 18.1.

Regarding the impact of alien plant species on Natura 2000 habitats and its spreading potential, five habitats from DDBR revealed the following: the annual vegetation on drift lines of habitat 1210 is strongly modified by the presence of Xanthium italicum; habitat 1310 Salicornia and other annuals colonising mud and sand are invaded by Symphyotrichium ciliatum and Xanthium italicum (up to $40 \%$ coverage) at Sacalin island and the Sulina area; habitat 1410 Mediterranean salt meadows, characterised by the presence of Juncus maritimus and Juncus littoralis, is in a very good state in Sf. Gheorghe area, but strongly overrun by Elaeagnus angustifolia in Sulina and invaded by Ambrosia artemisiifolia at Sacalin island; 1530* Ponto-Pannonic salt-steppes and salt-marshes is only rarely invaded by Amaranthus blitoides or Amaranthus blitum subsp. emarginatus; habitat 2110, Embryonic shifting dunes, is strongly modified by Xanthium italicum often with A-D 1 and $100 \%$ frequency, Conyza canadensis, Cuscuta campestris and Amorpha fruticosa (Anastasiu 2011).

The most important element in DDBR is the hydrological system (branches, channels, and lakes). In other words, water circulation and distribution are at the core of this wetland. While aquatic habitats are invaded by Azolla filiculoides and Elodea nuttallii, which competes against aquatic communities (Anastasiu et al. 2007), riparian and alluvial habitats are invaded especially by Amorpha fruticosa, which often forms the monodominant communities Fraxinus 
Table 18.1 Plant communities within the Danube Delta Biosphere Reserve mainly consisting of alien plants based on field research (Anastasiu 2011)

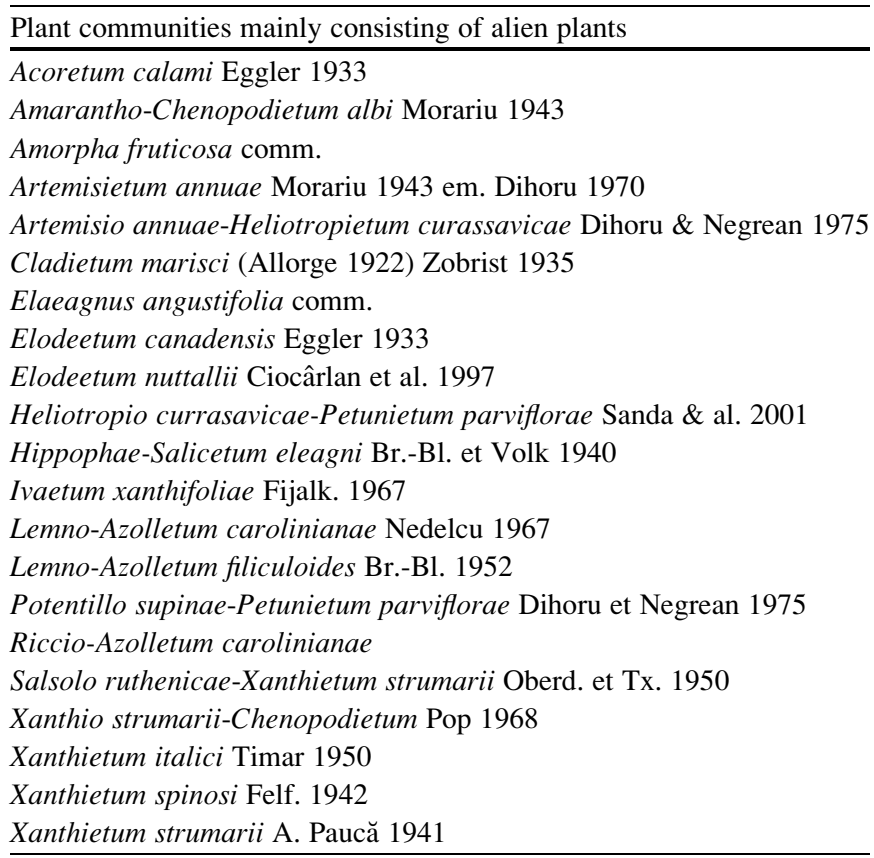

pennsylvanica, Xanthium spp., Eclipta prostrata, Lindernia dubia, and Dysphania ambrosioides (Anastasiu et al. 2007). However, most of the alien species within DDBR are present in ruderal vegetal communities strongly influenced by anthropogenic activities, while fewer of them are found in natural and semi-natural communities (Anastasiu 2011) (see Table 18.2).

Figure 18.1 presents a map with the spreading potential of invasive species. The dark red colour (e.g. 5) shows the core areas, where species are considered to have a high rate of spreading. In order to enhance the vulnerability of DDBR strictly protected areas are presented as well.

\subsection{Discussion}

\subsubsection{Climate Change-Related Features of Invasive Species}

Dragotă et al. (2011) explain that DDBR's climatic frame originates from the interaction between the main positive weather parameters and extremes. The most climatic extremes from Romania are: the uppermost air temperature values; 
Table 18.2 Alien plant species recorded in different types of natural and semi-natural plant communities/Natura 2000 habitats

\begin{tabular}{|c|c|c|}
\hline Invasive species & $\begin{array}{l}\text { Plant community (Natura } 2000 \\
\text { habitat type) }\end{array}$ & Qualitative Index \\
\hline $\begin{array}{r}\text { Amaranthus } \\
\text { blitoides }\end{array}$ & Artemisietum maritimae $(1530 *)$ & $\mathrm{AD}+-1, \mathrm{~F} \leq 50 \%$ \\
\hline $\begin{array}{l}\text { Amaranthus } \\
\text { blitum subsp. } \\
\text { emarginatus }\end{array}$ & Eleocharidetum acicularis (3130) & $\mathrm{AD}+, \mathrm{F} 100 \%$ \\
\hline $\begin{array}{l}\text { Ambrosia } \\
\quad \text { artemisiifolia }\end{array}$ & $\begin{array}{l}\text { 1: Hordeo murini-Cynodontetum } \\
\left(1530^{*}\right) \text {; } \\
\text { 2: Juncetum maritimi }(1410)\end{array}$ & $1: \mathrm{AD}+-1 ; 2: \mathrm{AD}+$ \\
\hline $\begin{array}{l}\text { Amorpha } \\
\quad \text { fruticosa }\end{array}$ & $\begin{array}{l}\text { 1: Atripliceto hastatae - Cakiletum } \\
\quad \text { euxinae (1210); } \\
\text { 2: Salicetum albae }\left(91 \mathrm{E} 0^{*}\right) \text {; } \\
\text { 3: Rubo caesii - Salicetum cinereae; } \\
\text { 4: Salicetum triandrae; } \\
\text { 5: Calamagrostio epigeji- } \\
\quad \text { Hippophaëtum rhamnoidis } \\
\quad(2160) \text {; } \\
\text { 6: Argusio-Petasitetum spuriae } \\
\quad\left(2130^{*}\right) \text {; } \\
\text { 7: Elymetum gigantei }(2110)\end{array}$ & $\begin{array}{l}1: \mathrm{AD}+; 2: \mathrm{AD}+-4 ; 3: \mathrm{AD}+-3 ; 4: \\
\quad \mathrm{AD}+; 5: \mathrm{AD}+; 6: \mathrm{AD}+; 7: \mathrm{AD}+ \\
\quad \mathrm{F} \leq 10 \%\end{array}$ \\
\hline Azolla filiculoides & $\begin{array}{l}\text { Lemno-Hydrocharitetum morsus- } \\
\text { ranae }(3150), \text { Lemno-Salvinietum } \\
\text { natantis }(3150) \text { and Lemno- } \\
\text { Azolletum carolinianae }(3150)\end{array}$ & coverage of water surface up to $85 \%$ \\
\hline $\begin{array}{l}\text { Conyza } \\
\quad \text { canadensis }\end{array}$ & $\begin{array}{l}\text { 1: Elymetum gigantei }(2110) \text {; } \\
\text { 2: Convolvuletum persici }(1210) \text {; } \\
\text { 3: Plantaginetum coronopi }(2110) \text {; } \\
\text { 4: Argusio-Petasitetum spuriae } \\
\quad\left(2130^{*}\right)\end{array}$ & $\begin{array}{l}1: \mathrm{AD}+-1, \mathrm{~F} \leq 60 \% ; 2: \mathrm{AD}+; 3: \\
\quad \mathrm{AD}+\end{array}$ \\
\hline $\begin{array}{l}\text { Elaeagnus } \\
\quad \text { angustifolia }\end{array}$ & $\begin{array}{l}\text { 1: Elymetum gigantei }(2110) \text {; } \\
\text { 2: Plataginetum coronopi }(2110) \text {; } \\
\text { 3: Juncetum maritimi }(1410) ; \\
\text { 4: Calamagrostio epigei- } \\
\text { Hippophaëtum rhamnoides } \\
\quad(2160)\end{array}$ & $\begin{array}{l}\text { 1: } \mathrm{AD}+; 2: \mathrm{AD}+; 3: \mathrm{AD}+-4 ; 4: \mathrm{AD} \\
\quad+;\end{array}$ \\
\hline Elodea nuttallii & Ceratophylletum demersii (3150) & $\mathrm{AD}+-2$ \\
\hline $\begin{array}{l}\text { Euphorbia } \\
\text { maculata }\end{array}$ & $\begin{array}{l}\text { 1: Plantaginetum coronopi }(2110) \text {; } \\
\text { 2: Trifolio fragifero-Cynodontetum } \\
\quad\left(1530^{*}\right)\end{array}$ & $1: \mathrm{AD}+-2 ; 2: \mathrm{AD}+$ \\
\hline Lindernia dubia & $\begin{array}{l}\text { Dichostylido michellianae- } \\
\text { Gnaphalietum uliginosi (3130); }\end{array}$ & $\mathrm{AD}+$ \\
\hline $\begin{array}{l}\text { Symphyotrichium } \\
\quad \text { ciliatum }\end{array}$ & $\begin{array}{l}\text { 1: Argusietum sibiricae (1210); } \\
\text { 2: Acorelletum pannonici (1310); }\end{array}$ & $1: \mathrm{AD}+; 2: \mathrm{AD}+$ \\
\hline
\end{tabular}


Table 18.2 (continued)

\begin{tabular}{|c|c|c|}
\hline Invasive species & $\begin{array}{l}\text { Plant community (Natura } 2000 \\
\text { habitat type) }\end{array}$ & Qualitative Index \\
\hline $\begin{array}{l}\text { Xanthium } \\
\quad \text { italicum }\end{array}$ & $\begin{array}{l}\text { 1: Argusietum sibiricae (1210); } \\
\text { 2: Atripliceto hastatae-Cakiletum } \\
\quad \text { euxinae (1210); } \\
\text { 3: Convolvuletum persici (1210); } \\
\text { 4: Acorelletum pannonici (1310); } \\
\text { 5: Elymetum gigantei (2110); } \\
\text { 6: Suaedo-Kochietum hirsutae } \\
\quad \text { (1310); } \\
\text { 7: Calamagrostio epigei- } \\
\quad \text { Hippophaëtum rhamnoides } \\
\quad \text { (2160); } \\
\text { 8: Suaedeto maritimae (1310) }\end{array}$ & $\begin{array}{c}1: \mathrm{AD}+; 2: \mathrm{AD}+; 3: \mathrm{AD}+; 4: \mathrm{AD}+; 5 \\
\mathrm{AD}+-3, \mathrm{~F} 10-100 \% ; 6: \mathrm{AD}+; 7 \\
\mathrm{AD}+; 8: \mathrm{AD}+-3, \mathrm{~F} \leq 100 \%\end{array}$ \\
\hline $\begin{array}{l}\text { Xanthium } \\
\text { spinosum }\end{array}$ & $\begin{array}{l}\text { Trifolio fragifero-Cynodontetum } \\
\qquad\left(1530^{*}\right)\end{array}$ & $\mathrm{AD}+, \mathrm{F}<10 \%$ \\
\hline
\end{tabular}

the lowest mean multi-annual precipitation amounts; the highest precipitation amounts fallen in short intervals ( 24 and $48 \mathrm{~h}$ ) due to extreme weather events; extended periods of dryness and drought phenomena, thus ranking the area among the first three in the country in terms of frequency, duration and intensity; high wind speeds and frequencies, this yields the highest wind power energy in the country; high degree of vulnerability to strong winds $(\geq 16 \mathrm{~m} / \mathrm{s})$; increased frequency and intensity of dangerous climatic events (e.g. heavy rains, fog, blizzards).

Changing climatic conditions influence three essential elements of invasion: the source location, the pathway, and the destination (Dangles et al. 2008; Hellmann et al. 2008). Species that tolerate a wide range of climatic conditions could become the most successful invaders (Taush 2008). For example, precipitation variations could cause water-demanding/resistant species to outcompete one another (Fig. 18.2). The average annual precipitation of DDBR decreases from west (Tulcea $-438.4 \mathrm{~mm}$ ) to east (Sf. Gheorghe $-403.6 \mathrm{~mm}$ ).

From the perspective of alien's bio-geographical origin, rising temperatures would allow some species of Mediterranean origin to spread northwards and enhance the winter survival chances of some other organisms (Dragotă et al. 2011). Phenological stages are sensitive to temperature. It is more likely for annual plants to flower earlier than it is for perennials, and more likely for insect-pollinated plants than for wind-pollinated ones (Fitter and Fitter 2002).

Various flowering phases have been registered for the same species in the same period of time but at different locations (Tulcea and Sf.Gheorghe) within DDBR (Fig. 18.3). At the sea side flowering phases are now occurring earlier. The average annual temperature in Tulcea is $11^{\circ} \mathrm{C}$ and in Sf. Gheorghe $12{ }^{\circ} \mathrm{C}$ (Dragotă et al. 2011). Monthly average of daily extreme temperatures have a significant role in the distribution of different phenological phases, as they are calculated from instantaneous values at different moments of the day, measured with maximumminimum thermometers representing the true contrast between day and night. 


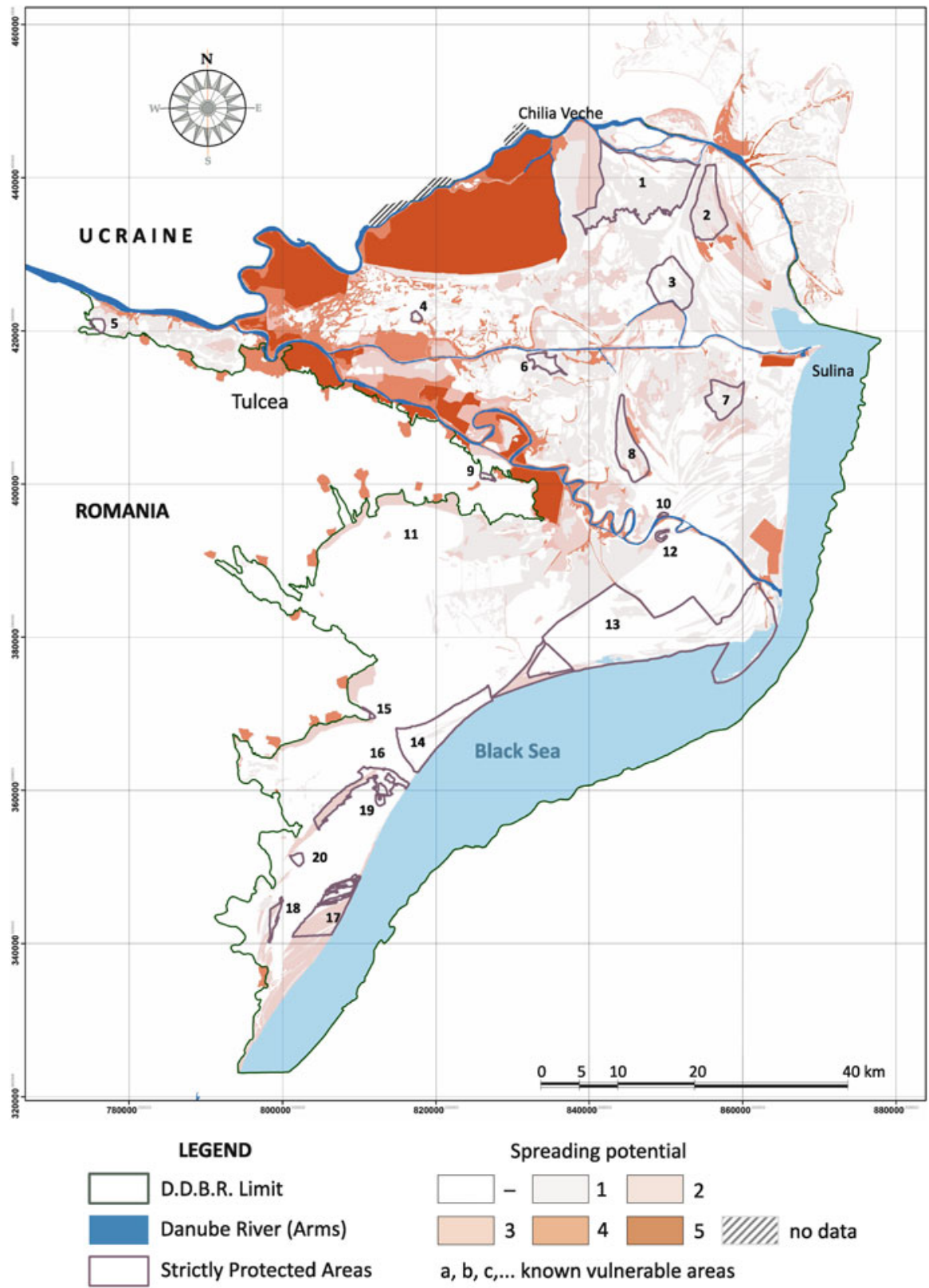

Fig. 18.1 Spreading potential of invasive plant species in DDBR

In January monthly averages of daily maximum temperatures are positive, ranging from 3 to $4{ }^{\circ} \mathrm{C}$ in the entire area, increasing in July to over $25^{\circ} \mathrm{C}$ in the fluvialmaritime part and Razim-Sinoe lake complex, to over $26^{\circ} \mathrm{C}$ in the central regions of the DDBR, and to over $27^{\circ} \mathrm{C}$ in the western parts. Climate change effects, such 


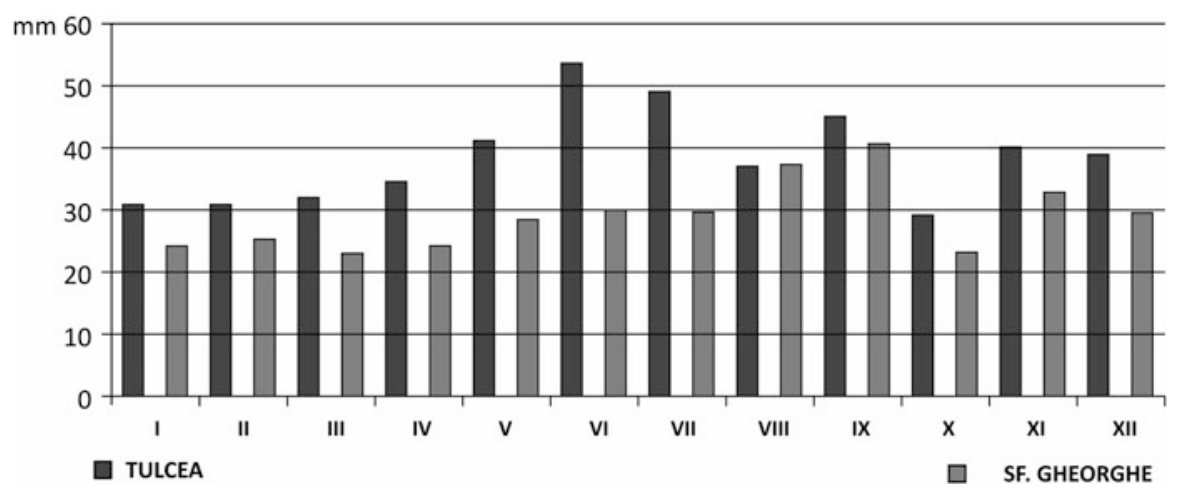

Fig. 18.2 Mean annual precipitation amounts in the Danube Delta Biosphere Reserve (1961-2007) (Dragotă et al. 2011)

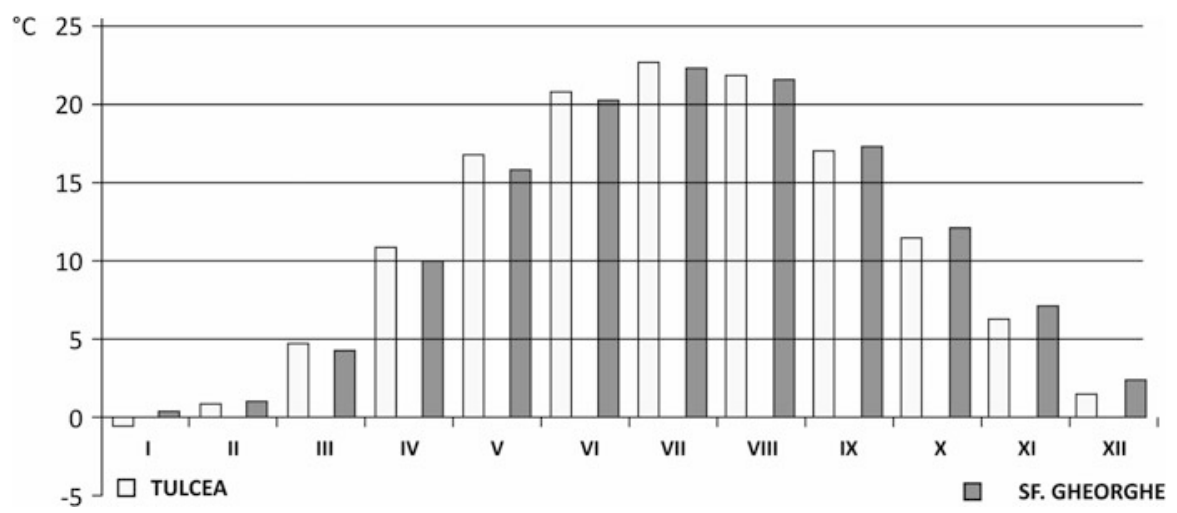

Fig. 18.3 Mean annual air temperatures in the Danube Delta Biosphere Reserve (1961-2007) (Dragotă et al. 2011)

as extreme duration of droughts, low temperatures, or floods in wetlands can haste the spreading of alien species. By comparing alien plants to natives ones, it has been observed that Fraxinus pennsylvanica, Ailanthus altissima, Amorpha fruticosa, and Morus alba are very resistant to these phenomena (Anastasiu and Negrean 2007). The actual spreading of alien ligneous species was not entirely based on their adaptive capacity given that most of them were massively planted in the past (Anastasiu and Negrean 2009). The species' resistance to frost is high, even though its spindles freeze every year. The first small plants begin to appear after the last frost period of the year when the soil is saturated with water and the evaporation process of water from soil is intense (Gregory and James 2003; Harold et al. 2005). The findings of previous studies revealed that the germination of seeds from Amorpha fruticosa, Fraxinus pennsylvanica, and Robinia pseudoacacia is influenced by both low temperatures below $16{ }^{\circ} \mathrm{C}$ and duration (Doroftei et al. 2005). With regard to distribution within DDBR, it may be mentioned that alien species' have been identified in almost all types of areas, environmental conditions, and habitat types. 


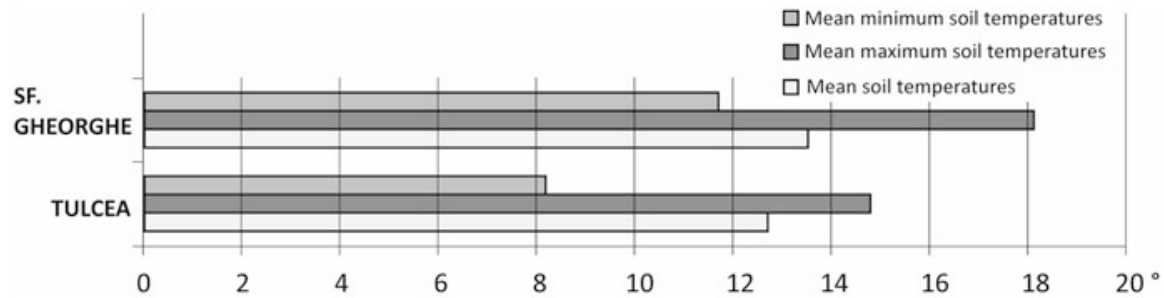

Fig. 18.4 Mean annual soil temperature parameters in the Danube Delta Biosphere Reserve (1961-2007) (Dragotă et al. 2011)

But the species' abundance and dimensions vary from area to area. Generally, the alien species have a preference for gleisoil $68 \%$, alluvial soils $11 \%$, and shifting sand hills $8 \%$; they also require a poor and moderate-drained soil (Munteanu and Curelariu 1996), but they are able to grow on poor soils and withstand the floods in DDBR. Although their development needs well-drained soils, they can resist in drought conditions (Gregory and James 2003). Gleditsia triacanthos can also tolerate strong winds but is unable to adapt to the coast area even under optimum conditions (Ailanthus altissima, Amorpha fruticosa, Fraxinus pennsylvanica) because of the winds from the sea. The exceptions are Elaeagnus angustifolia and Lycium barbarum as they do not require a soil with a specific pH to develop (Doroftei et al. 2005). They have a higher abundance and resistance in fluvial (western part) than in fluvial-maritime (eastern part) delta areas; the difference between these sectors consists in the amount of precipitation (Fig. 18.2), air (Fig. 18.3), and soil temperature (Fig. 18.4), and secondary, in drainage, salinity, soil texture (Munteanu and Curelariu 1996), and vegetation architecture type.

Furthermore, natural disturbances, such as fire regime, flood, bank-slides, and tree falls caused by dryness also provide good conditions for the development of alien species. The most abundant invasive species in DDBR are: around lakes and river banks - Acer negundo, Ailanthus altissima, Amaranthus blitum subsp. Emarginatus, Ambrosia artemisiifolia, Amorpha fruticosa, Azolla filiculoides, Conyza canadensis, Elaeagnus angustifolia, Elodea nuttallii, Lindernia dubia and Robinia pseudoacacia; in seaside areas - Amorpha fruticosa, Elaeagnus angustifolia, Euphorbia maculate, Lycium barbarum, Symphyotrichium ciliatum and Xanthium italicum; in localities - Acer negundo, Robinia pseudoacacia, Ailanthus altissima, Lycium barbarum and Xanthium spinosum.

\subsubsection{Management Priorities and Strategies Related to Climate Changes}

The research of Anastasiu (2011), Ciocârlan (2011) and Sîrbu and Oprea (2011) indicates that the number of alien plant species is increasing within DDBR. One of 
the reasons is that of all places in Romania DDBR is the most exposed to alien species through the many possible gates of their introduction: Constanţa, Sulina, Tulcea, Brăila, and Galaţi harbours (Anastasiu and Negrean 2009). Another reason is that certain plants communities are not well established. Therefore, in a climate change-induced changing landscape invasive species find opportunities for settling themselves by different dispersal factors (e.g. hydrological, wind). Presently, DDBR's management plan (2007-2013) provides only the action of inventorying invasive species and recommends some precautionary measures for their management that are not related to climate change. Also, in accordance with the 5th Convention on Biological Diversity and key directions of Seville's Strategy (UNESCO 1996), it recommends control or attenuation of climate changes in order to maintain a good habitat state. Among the potential measures that may be taken within DDBR in order to prevent negative effects of the invasive species in relation with extreme climate events are keeping the present population of some invasive species in control; maintaining a good habitat status in strictly protected areas by monitoring the newly arrived species; identifying new potential areas in order to replant species with decreasing populations because of environment frequent variations; changing the management of some habitat types by means of reducing climate change effects with minimum long-term consequences. The biggest challenge is the uncertainty of long-term effects that actions taken in present climate change conditions might have. Even if the present actions seem to be the most appropriate for the actual conditions there is no certainty that they will have the same effect in future climatic conditions. Scenarios combined with expert knowledge are needed at the local level in order to reduce this uncertainty. In this regard one example are mechanical control methods that are useful to some species in particular portions of their range. If warmer winter temperatures allow these plants to overwinter, management will have to be more aggressive and sustained and, thus, will be more expensive (Hellmann et al. 2008). Furthermore, it is necessary to ensure high-quality information about climate changes is available for park rangers training in order to enhance the capability of adapting and applying the required measures.

Climate change adaptation is being undertaken through management measures in order to reduce potential impacts of invasive species spreading in DDBR habitats. Priority challenges, responsive measures and their actions with possible risks are listed below for the Natura 2000 habitat types 1210, 1310, 1410, 1530*, 2110, 2130*, 2160, 3130, 3150 and 91E0*.

I. Challenge: habitat conservation; (a) Measure: identify areas that are likely to be resilient to climate change and support a broad range of plant species under changed conditions; Actions: identify and map high priority areas for conservation using information on species distributions, habitat classification, and land cover; spot the most problematic invasive plant species, their coverage, and spreading potential areas. Risks/Uncertainty: lack of implementation capacity because of the knowledge gap on habitats conservation; in the long term unpredictable changes of climate can sustain the propagule availability and, thus, the spreading of invasive plant species.

(b) Measure: restore habitat features; Action: restore degraded habitats to reduce species vulnerability by creating refuge areas in a changing climate; 
prioritise projects whose conservation targets are invasive plant species and resilience in a changing climate; Risks/Uncertainty: the lack of political will; the features of restored habitats cannot be maintained due to climate change pressures.

II. Challenge: species and habitat management in the context of climate change; Measure: bring the management plan up-to-date by taking climate change risks in account and support adaptation; Actions: use management practices that are already being successfully applied in other protected areas; take climate change effects, potential risks, and invasive plant species distribution for entire Danube River Basin into account; improve risk assessments and vulnerability scenarios to be able to develop and choose suitable measures; use species distribution models to identify new potential habitats for translocation of endangered plants; Risks/Uncertainty: insufficient data for assessments and scenarios; lack of interpretation ability in the field of predicted results; the long-term effects of actions taken in present climate change conditions can prove inefficient;

III. Challenge: improve capacity for effective management in a changing climate; (a) Measure: increase awareness of invasive species threats in climate change context and increase the capacity of stakeholders to implement adaptation programmes for habitats and plant species; Actions: conduct training on different levels of organisation (e.g. park rangers, head managers) initiating hypothetical management activities on extreme climate events and trends of invasion; develop a network of training opportunities and materials addressing climate change impacts on protected areas management through agreements with universities and research institutes; Risks/Uncertainty: lack of communication interest;

(b) Measure: assist a coordinated response to climate change between protected areas administration, stakeholders, nature protection agencies, and specific NGO's; Actions: identify and address conflicting management objectives of involved decision-makers and find effective policies and methods for climate change pressures; develop trans-boundary common management to adapt to and mitigate climate change impacts in shared areas (Danube Delta Biosphere Reserve - Romania and Ukraine); Risks/Uncertainty: possible future changes in management objectives of protected areas;

IV Challenge: reduce non-climate pressures; (a) Measure: slow and reverse habitat loss and fragmentation; Actions: collaborate with environmental agencies to evaluate historical water fluctuations and improve water management options to protect or restore aquatic habitats; identify the range of most disturbing activities in habitats on a map and compare it with habitats and invasive plant species distribution maps in order to identify vulnerable areas. This reduces/changes pressure activity on habitats and enables restoration, where loss and fragmentation due to invasive plant species occurred; increase restoration, enhancement, and conservation of riparian zones; create buffer zones to agricultural areas minimising the spreading potential of invasive plant species to natural areas; Risks/Uncertainty: invasive plant species can easily spread in the present climate conditions. Insufficient correlation between control/eradication measures of invasive species and non-climate pressure activities.

(b) Measure: involve, assess, and improve existing programmes to prevent, control, and eradicate invasive species; Actions: develop different approaches to 
detect established invasive species, including entries monitoring; raise public awareness by non-formal activities and media to foster understanding for regulations and potential risks for native species and habitats; overall risk assessment to identify actions and prioritise responses to invasive species that pose the greatest threats to habitats and species; Risks/Uncertainty: inefficient knowledge transfer to stakeholders and the public; no cooperation between decision-makers. no sufficient funds for control/eradication measures.

\subsection{Conclusions}

Regardless that DDBR is a wetland, dryness and drought have the greatest intensity and frequency in Romania. DDBR's annual average quantities of precipitation decrease towards the sea shore area, while the average temperature increases. In these conditions, Natura 2000 habitats types 1210, 1310, 1410, 1530*, 2110, 2130*, $2160,3130,3150$ and $91 \mathrm{E} 0 *$ are exposed to the spreading potential of invasive species. The biggest challenge is the uncertainty of long-term effects of actions taken for the control and eradication of invasive species in current climate changing conditions. More research into dynamic modelling and scenarios tools that should be developed is needed. This should be done both at a regional and local level involving experts in order to understand extreme events and how to diminish their effects by applying appropriate measures.

Open Access This chapter is distributed under the terms of the Creative Commons Attribution Noncommercial License, which permits any noncommercial use, distribution, and reproduction in any medium, provided the original author(s) and source are credited.

\section{References}

Anastasiu, P. (2011). Studiul complex asupra plantelor alohtone din Delta Dunării în vederea stabilirii impactului ecologic, evaluării riscului şi elaborării măsurilor minime pentru managementul acestora. Sinteza lucrării. Bucureşti: Universitatea din Bucureşti.

Anastasiu, P., \& Negrean, G. (2007). Invadatori vegetali în România. Bucureşti: Editura Universităţii din Bucureşti.

Anastasiu, P., \& Negrean, G. (2009). Neophytes in Romania. In L. Rakosy \& L. Momeu (Eds.), Neobiota din Romania (pp. 66-97). Cluj Napoca: Editura Presa universitară Clujană.

Anastasiu, P., Negrean, G., Bașnou, C., Sîrbu, C., \& Oprea, A. (2007). A preliminary study on the neophytes of wetlands in Romania. In W. Rabitsch, F. Essl, \& F. Klingenstein (Eds.), Biological invasions - From ecology to conservation (NEOBIOTA) (Vol. 7, pp. 181-192). Berlin: Institute of Ecology.

Ciocârlan, V. (2011). Vascular flora of the Danube Delta, Analele ştiinţifice ale Universităţii “Al. I. C.”, Tomul LVII, fasc. 1, s. II a. Biologie vegetală, Iaşi: Editura Universitătii “Al. I. C." $41-64$. 
Dangles, O., Carpio, C., Barragan, A. R., Zeddam, J.-L., \& Silvain, J.-F. (2008). Temperature as a key driver of ecological sorting among invasive pest species in the tropical Andes. Ecological Applications, 18, 1795-1809. doi:10.1890/07-1638.1.

Doroftei, M., Mierlă, M., \& Marinov, M. (2005). Ecology of some alien plant species in Danube Delta. Ovidius University Annals of Natural Sciences, Biology - Ecology Series, 9(1), 33-40.

Dragotă, C. S., Grigorescu, I., Dumitraşcu, M., Doroftei, M., Mierlă, M., \& Năstase, M. (2011). Climatic potential and key meteorological drivers for the dynamics of invasive terrestrial plant species in Romanian protected areas. 3rd international symposium on weeds and invasive plants October 2-7, 2011 in Ascona, Switzerland.

Fitter, A. H., \& Fitter, R. S. R. (2002). Rapid changes in flowering time in British plants. Science, 296(5573), 1689-1691.

Gregory, M. R., \& James, T. C. (2003). Invasive species vectors and management strategies. London: Island Press.

Hanganu, J., Dubyna, D., Zhmud, E., Grigoraş, I., Menke, U., Drost, H., Ştefan, N., \& Sârbu, I. (2002). Vegetation of the biosphere reserve "Danube Delta" with transboundary vegetation map on a 1: 150000 scale, Danube Delta National Institute, Romania; M.C. Kholodny Institute of Botany \& Danube Delta Biosphere Reserve, Ukraine and RIZA The Netherlands. RIZA Rapport 2002049, Lelystad.

Harold, A. M., Richard, N. M., Jeffrey, A. M., Laurie, E. N., Peter, J. S., \& Jeffrey, K. W. (2005). Invasive alien species. London: Island Press.

Hellmann, J. J., Byers, J. E., Bierwagen, B. G., \& Dukes, J. S. (2008). Five potential consequences of climate change for invasive species. Conservation Biology, 22(3), 534-543. doi:10.1111/j.1523 1739.2008.00951.x.

Leech, S. M., Almuedo, P. L., \& O'Neill, G. (2011). Assisted Migration: Adapting forest management to a changing climate. BC Journal of Ecosystems and Management, 12(3), 18-34.

Munteanu, I., \& Curelariu, G. (1996). Thematic map of the Danube Delta - Head deposits 1:175000 scale (RIZA Rapport 1996055). Lelystad: Research Institute for Soil Science and Agrochemistry from Bucharest and Institute for Inland Water Management and Waste Water Treatment from Lelystad.

Richardson, D. M., \& Pysěk, P. (2006). Plant invasions: Merging the concepts of species invasiveness and community invisibility. Progress in Physical Geography, 30(3), 409-431.

Sanda, V., \& Arcuş, M. (1999). Sintaxonomia grupărilor vegetale din Dobrogea şi Delta Dunării. Piteşti: Editura Cultura.

Sîrbu, C. \& Oprea, A. (2011). Flora adventivă din România. Iaşi: Editura Universităţii “Alexandru Ioan Cuza".

Tausch, R. J. (2008). Invasive plants and climate change. Washington, DC: U.S. Department of Agriculture, Forest Service, Climate Change Resource Center.

UNESCO. (1996). Biosphere reserves: The Seville Strategy and the statutory framework of the World Network. Paris: UNESCO. 